\title{
Identificación de indicadores ambientales relacionados con el nivel de biodiversidad para determinar el turismo urbano sostenible utilizando geo tecnologías. Estudio de caso: Riobamba-Ecuador
}

\section{Identification of environmental indicators related to the level of biodiversity to determine sustainable urban tourism using geotechnologies. Case study: Riobamba-Ecuador}

Catalina Margarita Verdugo Bernal. ${ }^{1}$ Myriam Isabel Piray Quezada. ${ }^{2}$ Julia Desiree Velasteguí Cáceres ${ }^{3} \&$ Mario Geovanni Arias Guanga. ${ }^{4}$

\begin{abstract}
.
The incidence of Sustainable City Indicators turns out to be a key element in environmental management for the cities, which is why the survey of a comprehensive baseline of sustainability indicators in the city of Riobamba, Ecuador is undertaken, as the continuation of a ranking of cities sustainable, among which data from Quito, Guayaquil and Cuenca are the subject of a previous study (Verdugo, 2016). The measurement was made in the 5 urban parishes of Riobamba, given that the information is scarce. Eleven variables were collected based on the previous realization of the environmental component diagnosis in a first phase based on the review and analysis of other systems of global, regional and local indicators; Afterwards, it was determined that the areas to be studied will be initially, public space and georeferenced vegetation cover and finally those variables that are decisive in the level of sustainability of the city were weighted to issue subsequent recommendations to this reality.
\end{abstract}

\footnotetext{
${ }^{1}$ Escuela Superior Politécnica de Chimborazo, Facultad de Recursos Naturales, Chimborazo Ecuador, cverdugo@espoch.edu.ec

${ }^{2}$ Técnica especialista en Áreas protegidas del Ministerio de Ambiente Ecuador, myriampiray@yahoo.com

${ }^{3}$ Escuela Superior Politécnica de Chimborazo, Facultad de Recursos Naturales, Chimborazo Ecuador, julia.velastegui@espoch.edu.ec

${ }^{4}$ Consultor independiente de turismo y cultura. email: mario_21ma@hotmail.com
} 
Keywords: Tourism Indicators, Environmental, urban Sustainability, Geotechnologies, urban biodiversity.

\section{Resumen.}

La incidencia de los Indicadores de Ciudad Sostenible resulta ser un elemento clave en la gestión ambiental de las ciudades, por lo que se realiza la encuesta de una línea de base integral de indicadores de sostenibilidad en la ciudad de Riobamba, Ecuador, como la continuación de un ranking de ciudades. sostenible, entre los cuales los datos de Quito, Guayaquil y Cuenca son objeto de un estudio previo (Verdugo, 2016). La medición se realizó en las 5 parroquias urbanas de Riobamba, dado que la información es escasa. Once variables fueron recolectadas en base a la realización previa del diagnóstico del componente ambiental en una primera fase basada en la revisión y análisis de otros sistemas de indicadores globales, regionales y locales; Posteriormente, se determinó que las áreas a estudiar serán inicialmente, el espacio público y la cubierta de vegetación georreferenciada y, finalmente, las variables que son decisivas en el nivel de sostenibilidad de la ciudad fueron ponderadas para emitir recomendaciones posteriores a esta realidad.

Palabras clave: Indicadores de turismo, medio ambiente, sostenibilidad urbana, geotecnologías, biodiversidad urbana.

\section{Introduction.}

During the last decades in the field of environmental management, important efforts have been made to promote environmental indicators and sustainable development. At the end of the eighties, Canada and some European countries began this process; For its part, in Latin America, the first environmental indicators were assembled in the mid-nineties (Economic Commission for Latin America, 2007)

The State Coordinator of Coffee Producers of Oaxaca, (CEPCO, 2013), reveals that since the introduction of the idea of sustainable development in the eighties and its subsequent conceptualization as a harmonious triangle between economic growth, social equity and environmental conservation, academic discussions have increased significantly around the path to follow to achieve sustainable development, in the same way, questions have been raised about the main causes of environmental deterioration and global phenomena that deepen the economic, social and environmental gaps global, regional and / or local scale.

Organization of the United Nations, in the Conference on Housing and Sustainable Urban Development Habitat III, held in the city of Quito in October 2016, essential parameters for the identification of factors that directly influence the investigative work. It states that the main indicators related to sustainable development have focused basically on the environmental factor of sustainability, that is, environmental indicators have been the 
most commonly used to assess the state of the planet, as well as to observe the differences between the different regions, countries and cities. However, at the international level, some indexes have been developed that seek to integrate the various aspects of sustainable development, such as the Prosperity Index (Habitat III, 2016)

In Ecuador, the Ministry of the Environment has been working since 2010 on a System of Environmental Indicators that includes information for environmental issues such as: Atmosphere and Climate, Soils, Ecosystems, Marine and Coastal Resources, among others. However, within this system there are no indicators to assess the state of the environment at the municipal level, in the same way that there is no information about environmental performance in cities. (MAE, 2010)

Several cities participated on behalf of Ecuador in the construction of the Green Cities Index for the Latin American region. According to the data obtained at the time of the study, the city of Quito is located at a "Medium" level regarding its environmental sustainability, within the context of the 17 participating cities (Economist Intelligence Unit, 2010)

Within this panorama, this research proposes to identify information that will allow the future to determine indicators for environmental sustainability linked to the increase of biodiversity in the city of Riobamba, which will ecologically describe the state of sustainability in which it is located and allow to route an integral conservation process for the future.

\section{Objectives.}

The main objective of this study is to: Assess environmental indicators related to the level of biodiversity for the urban sustainability of Riobamba and this was possible developing the following specific objectives: a) Validate environmental indicators related to biodiversity for determine the level of urban sustainability; b) Generate a database using geo-information in the urban environment about public space and vegetation coverage; c) Apply a data matrix to determine the level of sustainability.

\section{Materials and Methods}

The analytical-descriptive method and field observation were used, through the analysis of secondary information from bibliographic sources and the collection of primary source data through participatory research between the Higher Polytechnic School of Chimborazo and the Municipality of Riobamba, whose objectives were fulfilled as follows:

1. Validate environmental indicators related to the increase of biodiversity to determine the level of urban sustainability in Riobamba. 
The diagnosis of the Environmental component in the increase of Riobamba biodiversity was made following the parameters:

- Access of citizens to green spaces

- Compensation to waterproofing and sealing: Permeability index

- Provision of trees in the public space

- Green runners

- A second layer of biodiversity in height

- A second layer of biodiversity in height: greening of facades

Taking as a starting point situations related to the analysis of urban biodiversity developed in different cities of Latin America and Europe, a compilation of essential factors that allow to know the reality of the city was carried out.

\section{a. Selection and classification of indicators}

The Urban Sustainability Indicators Plan is an instrument that responds to a certain more sustainable city model with the intention of quantitatively and qualitatively assessing the urbanization process of the city of Riobamba from an integral and systemic point of view with sustainability criteria.

Taking into account the aforementioned, the experiences of the countries that have carried out the studies on the urban biodiversity aspect have been used as an initial point to be analyzed and compared with the reality of the city of Riobamba.

In different cities or organizations such as; city of Vitoria-Gasteiz of Spain, the City Council of Malaga jointly with the European Union with the URBAN INITIATIVE URBAN SUSTAINABILITY INDICATORS, United Nations in conjunction with ECLAC in the project Application of urban sustainability indicators to social housing, Network of Networks of Sustainable Local Development, with the help of BCN Ecology, the Government of Spain and the Special Plan of Indicators of Environmental Sustainability of the Urban Development Activity of Seville, are the cities that carry out indicators of sustainability to urban biodiversity.

\section{b. Discrimination of the obtained indicators}

Using the information of cities that have applied the indicators for biodiversity, having a total of 24 indicators of sustainability, we have proceeded to the verification in the field if the indicators can be adapted to the city, and if the information required by the 
indicators exists in the GADM Riobamba, otherwise they have discriminated from the table, thus being the first indicators of the city.

The indicators were adapted to the reality of the city of Riobamba in order to have coherent results using the methodology consisting of secondary information collection, interviews, observation, field work, which are used by Spain, the UN, Ecology BCN, ECLAC and the cities that are in the process of analyzing sustainability, the same ones that when carrying out the studies only adapt the weights or update them to improve biodiversity in the urban area of the main cities.

\section{c. National and international observations}

Through the consultation of the international observations of the World Organization of the Departure (2010), the laws that govern within the Ecuadorian territory and of the competences of the GADM through the (COTAD 2016) the Territorial Organization of the GADM (municipality) Riobamba, will help us to observe if in the city, what is established by international observations is complied with as per the laws.

To fulfill the second objective: Generate a database using geoinformation in the urban area about public space and vegetation coverage.

- Field trips were made to collect the geographic data with the GPS.

- Through the information obtained from GADM Riobamba and ESPOCH's forestry school, the geographically referenced data were integrated, edited, analyzed and incorporated.

- The GIS (Geographical Information System) was used as a tool, by means of information on the location and representation on maps.

To fulfill the third objective: Apply a matrix to determine the level of sustainability.

The selected indicators were transferred to the Office Excel 2013 software, in which the degree of compliance with the criteria can subsequently be measured.

For the data matrix as explained by (Walter, 2013) and according to the needs that this work requires, the first results are generated that show the sustainability of biodiversity in the city of Riobamba.

The weights and statistical formulas that were used are those that have been handled in the aforementioned projects that will help measure the sustainability of Riobamba, at the same time observe the existing shortcomings within the urban area.

Eleven the results of the environmental measurement related to the increase in biodiversity in the parks of the Riobamba canton are obtained, the results will be 
systematized in order to discern and identify the sustainable areas where the greatest weakness or deficit is found. in the fulfillment of the weights.

Surveys were applied to know the satisfaction of the urban community on the existing parks in the city, determining a representative sample based on the formula of finite populations.

$$
n \frac{N(P * Q)}{(N 1)\left(\frac{e}{z}\right)^{2}(P * Q)}
$$

Where:
n: $\quad$ Sample size
$\mathrm{N}: \quad$ Studio Universe
P: $\quad$ Probability of occurrence (50\%)
Q: $\quad$ Probability of non-occurrence (50\%)
e: $\quad$ Error range $(5 \%)$
z: $\quad$ Confidence level $(1,96)$

\section{Results and discussion}

The investigation was conducted in Riobamba located in the province of Chimborazo, in the central inter-Andean area of Ecuador. Coordinates in UTM, Zone 17S, DATUM WGS 84

$$
\begin{array}{ll}
X: & 759607 \\
\text { Y: } & 9814770
\end{array}
$$

Altitud: 2754m.s.n.m. (Fuente: Cartografía base del Instituto Geográfico Militar. 2002).

After analyzing the environmental indicators from various sources at the global, regional and local levels, it was determined that the following are those of greater adaptability to the reality of Riobamba, especially to the vision that its population and local authorities have on environmental sustainability.

Due to the fact that the project has been compiling environmental indicators from 2016 to 2019, the amount of information on sustainability indicators, not only environmental, has become too large a repository to be presented in a single work. summarizes the indicators related to biodiversity measured in this specific work that has served to feed 
the database of the large project Measuring the sustainability indicators (economic, social, environment, culture, technology and politics) of Riobamba and its influence on activities such as tourism and others.

\section{Sustainability of Riobamba}

Table 1: Sustainability of Riobamba Matrix Evaluation

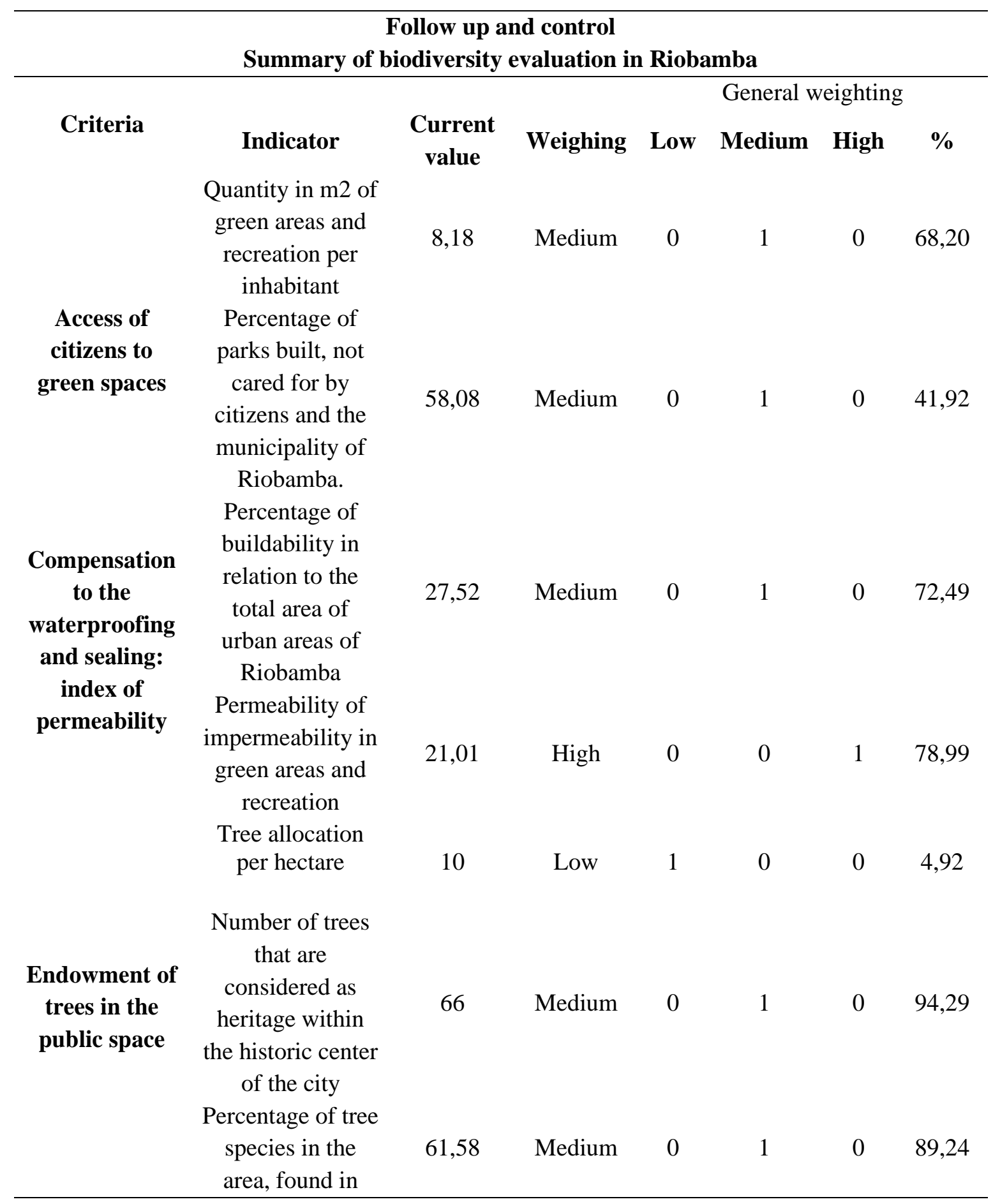




\begin{tabular}{|c|c|c|c|c|c|c|c|}
\hline & $\begin{array}{c}\text { parks and } \\
\text { recreation areas }\end{array}$ & & & & & & \\
\hline Green paths & $\begin{array}{l}\text { Percentage of } \\
\text { green corridors } \\
\text { allocated to the } \\
\text { total area of the } \\
\text { urban area of } \\
\text { Riobamba }\end{array}$ & 14,85 & Low & 1 & 0 & 0 & 49,50 \\
\hline $\begin{array}{l}\text { Percentage of } \\
\text { green } \\
\text { coverage in } \\
\text { green areas } \\
\text { and recreation }\end{array}$ & $\begin{array}{l}\text { Percentage of } \\
\text { green coverage in } \\
\text { green and } \\
\text { recreational areas }\end{array}$ & 78,99 & High & 0 & 0 & 1 & 112,85 \\
\hline \multirow[t]{2}{*}{$\begin{array}{c}\text { A second } \\
\text { layer of } \\
\text { biodiversity in } \\
\text { height }\end{array}$} & $\begin{array}{l}\text { Percentage of } \\
\text { buildings in the } \\
\text { historic center } \\
\text { that meet the } \\
\text { greening of } \\
\text { facades }\end{array}$ & 10,67 & Low & 1 & 0 & 0 & 7,73 \\
\hline & $\begin{array}{c}\text { General } \\
\text { sustainability }\end{array}$ & $\begin{array}{c}\text { Total } \\
\text { weighting }\end{array}$ & & 3 & 5 & 2 & 61,97 \\
\hline
\end{tabular}

Note: Arias, 2016

Figure 1. Level of Sustainability of Riobamba

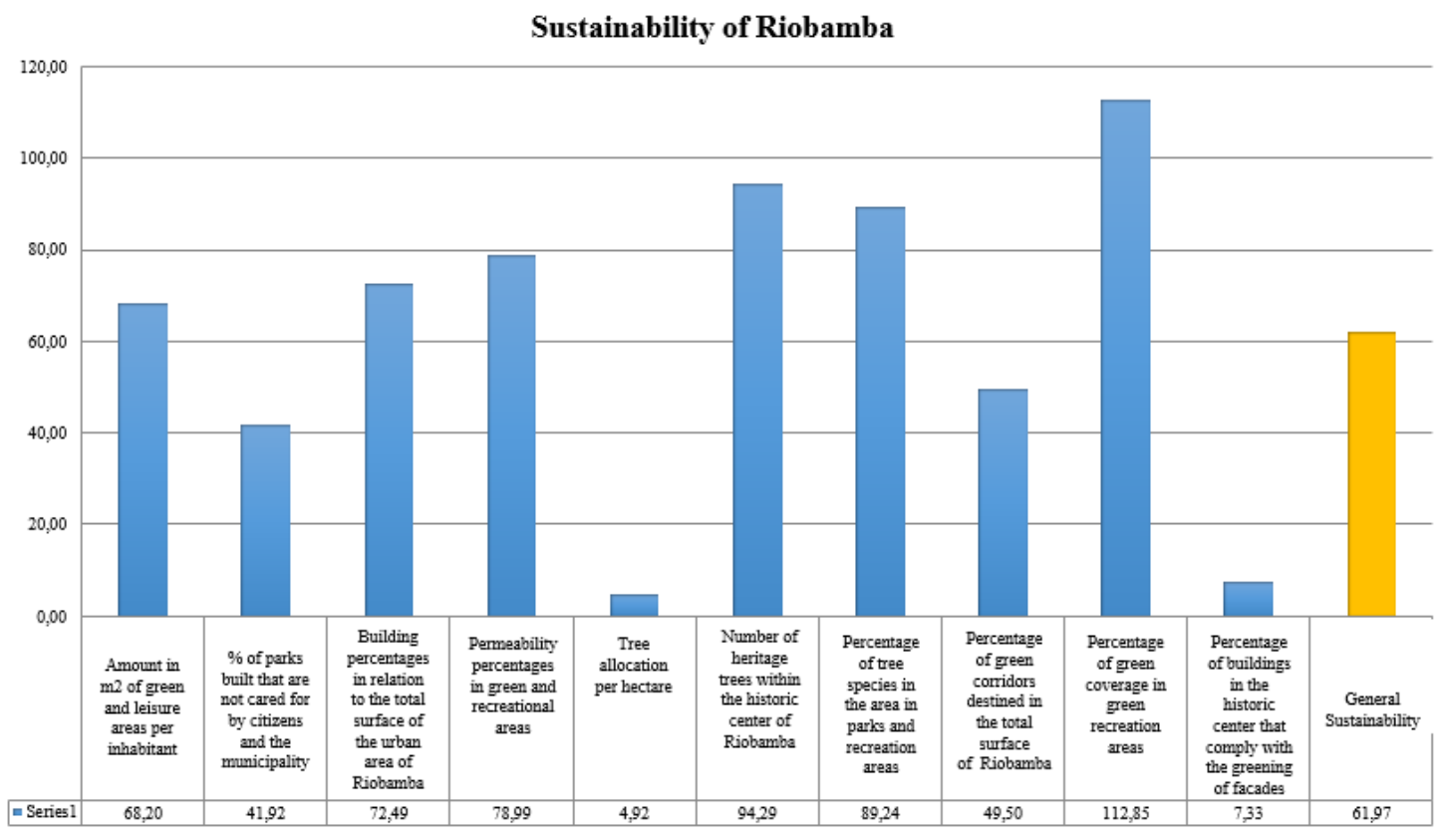

Note: Arias, M. 2016 


\section{Interpretation.}

Once the indicators were determined, we proceeded to assign percentage values to each one, considering as the maximum value, that is, $100 \%$, the beginning of the value at which the "high" category begins.

With the results obtained, it can be seen that the sustainability of Riobamba is in the category "Medium" corroborating the information in figure 1, it can be seen that there are low indicators such as the allocation of trees per hectare and the buildings of the historic center that comply with the greening of the facades, as average indicators the percentage of parks built that are not adequately cared for by the citizens and the municipality, the percentage of impermeability in green areas and of recreation, the percentage of tree species in the area, which are found in parks and recreation areas and the percentage of green corridors allocated to the total area of the urban area of the Riobamba canton; and high indicators being the amount in $\mathrm{m} 2$ of green areas and recreation per inhabitant, the percentage of buildable in relation to the total area of the urban areas of the canton, the number of trees that are considered as heritage within the historic center of the city and the percentage of green coverage in green areas and recreational areas, which allows Riobamba to be identified as a city that in its territorial planning has considered issues of sustainability in its biodiversity, however, there are environmental factors that must be improved so that it can meet with the necessary criteria to be considered as a city that applies international standards to be called "sustainable city" at the level of biodiversity within the urban area.

b) After applying the formula of the sample it was determined that the ideal number of surveys applied to the population is a number of 400, to know among other things its perseveration on the state of the environment of its city and the needs of green spaces for recreation.

Below is a summary of the main questions asked to the citizenship.

Table 2. Summary of questions asked to Riobamba's citizen

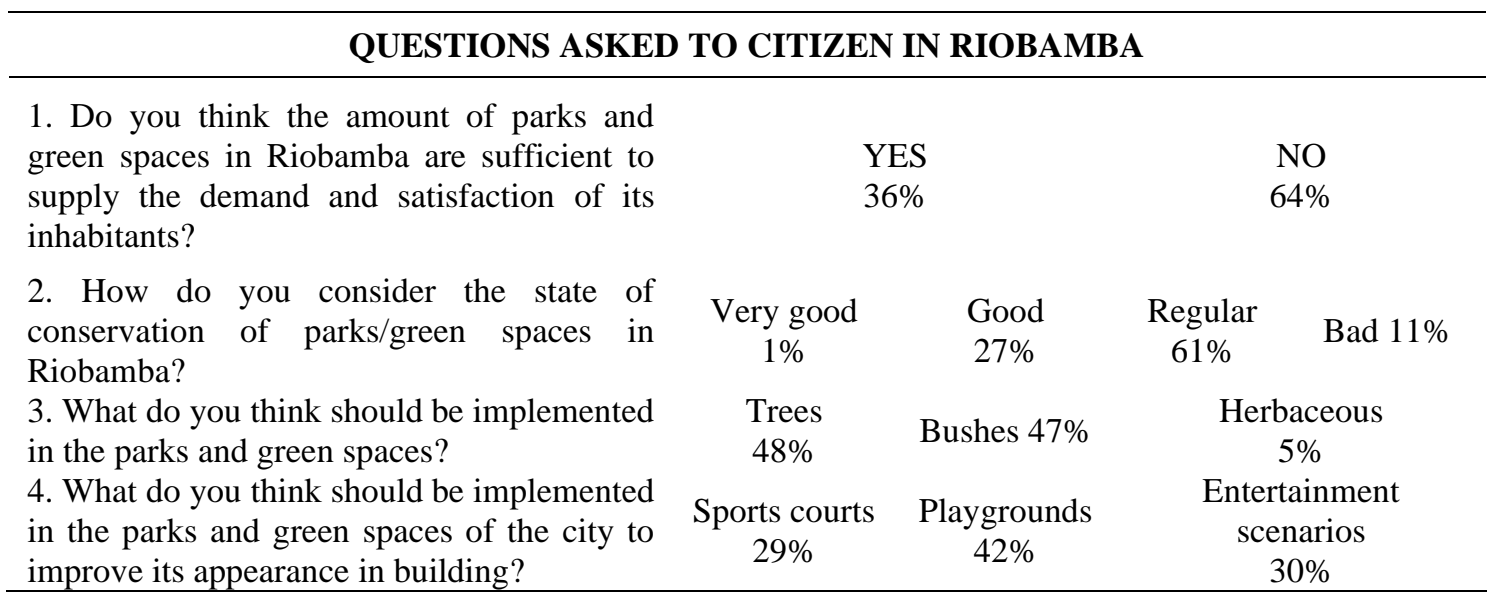


5. What material do you think should be implemented in the parks and green spaces to improve children's games?

6. Are you agree that musical, cultural and sportive events perform in these parks?

7. Your neighborhood has a suitable park?

8. Do you consider the parks/green spaces in your neighborhood are enough to satisfy the entire community?

9. How do you consider the state of conservation of parks and green spaces in your neighborhood?

10 . Do you know any municipal ordinance or regulations about caring parks and the sanctions that imply their carelessness?

11.Do you know if Riobamba can be classified as a sustainable city in relation to the parameters established in the Habitat III conference?

12. Do you believe that project should be carried out to improve the states of conservation, use, tourism and aesthetics of the parks and green spaces of the city?

$\begin{array}{cccc}\text { Wood } & & \text { Iron } & \text { Mixed } \\ 33 \% & & 17 \% & 50 \% \\ & \text { Yes } & & \text { No } \\ & 33 \% & & 8 \% \\ & \text { Yes } & \text { No } \\ 33 \% & 67 \% \\ & \text { Yes } & \text { No } \\ 21 \% & & 79 \%\end{array}$

\begin{tabular}{|c|c|c|c|}
\hline $\begin{array}{c}\text { Very good } \\
1 \%\end{array}$ & $\begin{array}{l}\text { Good } \\
22 \%\end{array}$ & $\begin{array}{c}\text { Regular } \\
50 \%\end{array}$ & Bad $28 \%$ \\
\hline \multicolumn{2}{|c|}{ Yes } & \multicolumn{2}{|r|}{ No } \\
\hline \multicolumn{2}{|c|}{$22 \%$} & \multicolumn{2}{|r|}{$79 \%$} \\
\hline \multicolumn{2}{|c|}{ Yes } & \multicolumn{2}{|r|}{ No } \\
\hline \multicolumn{2}{|c|}{$24 \%$} & \multicolumn{2}{|r|}{$76 \%$} \\
\hline \multicolumn{2}{|c|}{ Yes } & \multicolumn{2}{|r|}{ No } \\
\hline & & $8 \%$ \\
\hline
\end{tabular}

Note: Verdugo, 2019

c) In addition, the main green areas of the city were georeferenced and those in a state of deterioration, among other indicators that will be presented in subsequent works.

Figure 2. Green and recreational areas in Riobamba

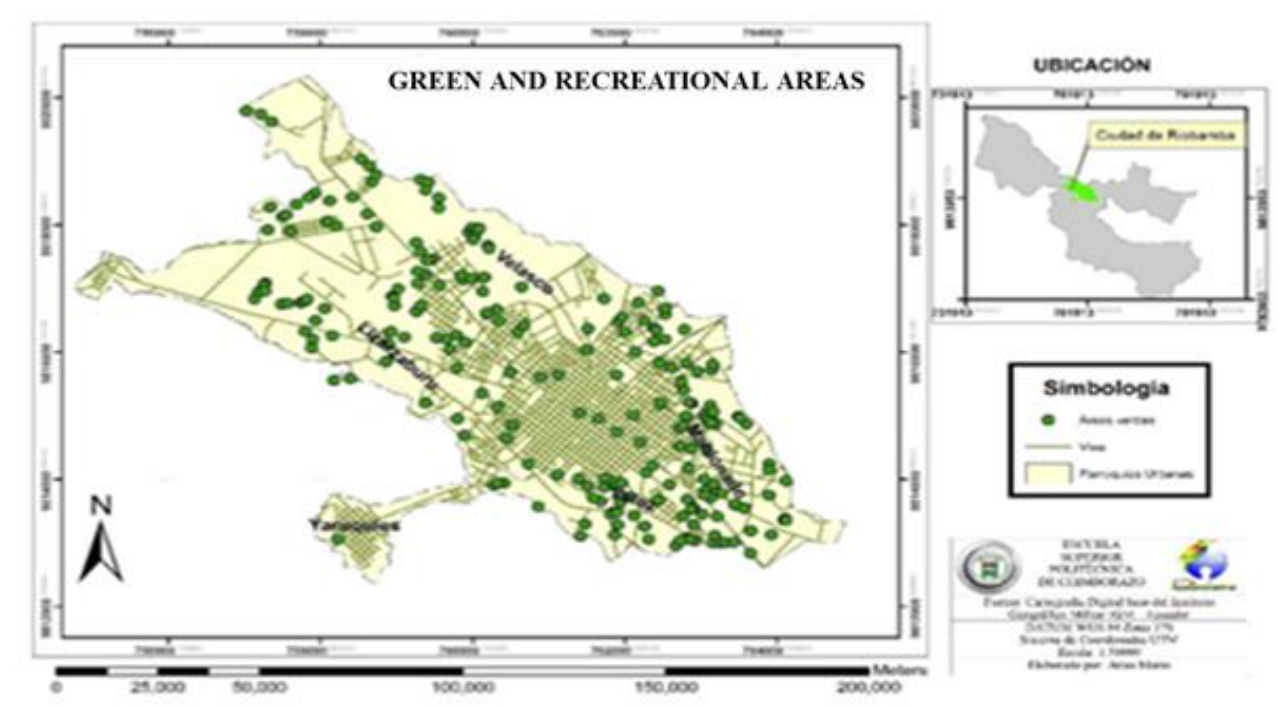

Note: Mario Arias 2016 and inventory of partks of Riobamba conducted by the School of Forestry ESPOCH 2012 
Figure 3. Green and recreational areas in Riobamba

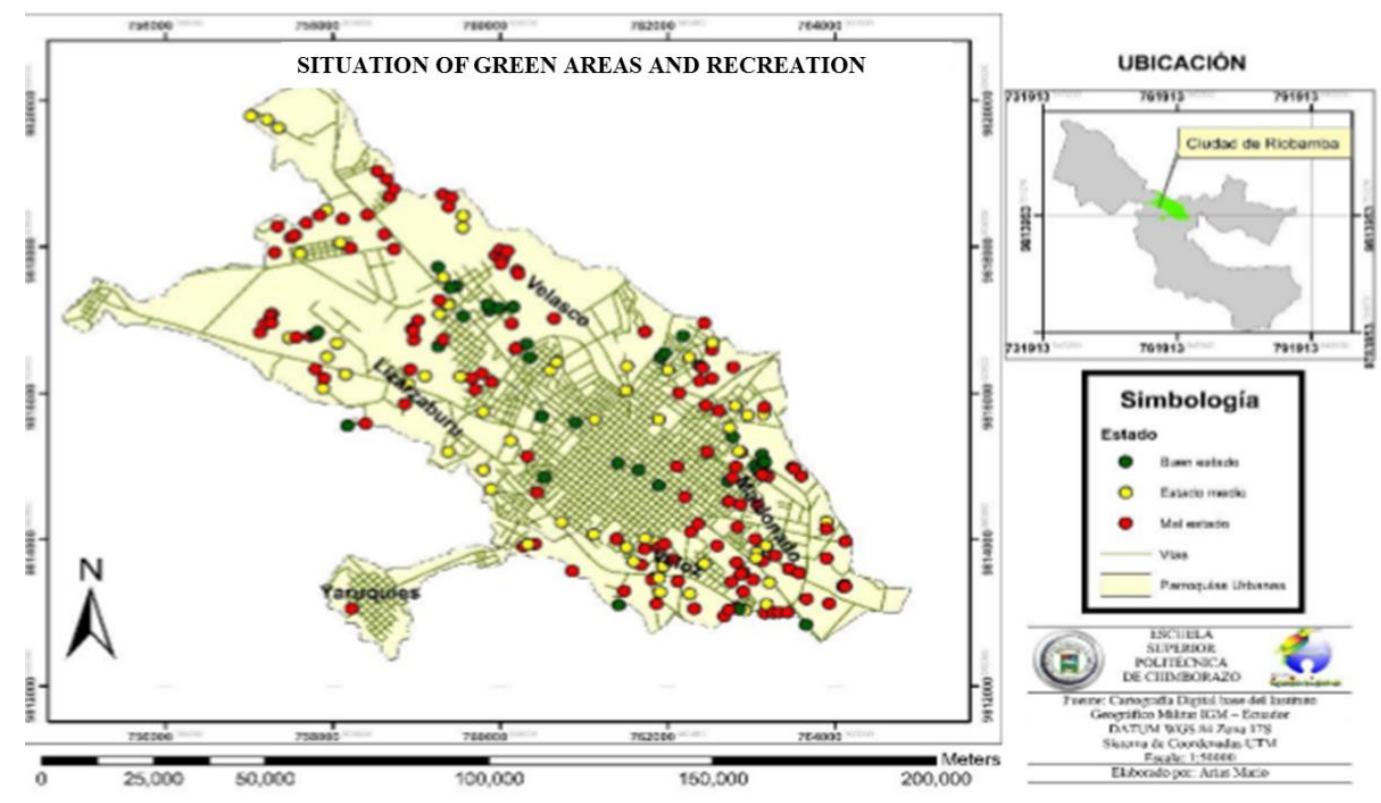

Note: Mario Arias 2016 and inventory of partks of Riobamba conducted by the School of Forestry ESPOCH 2012

d) Finally, a series of improvement recommendations were delivered and socialized to the Environmental Management of the municipality of Riobamba, where in the future it is intended to publish material for the population of Riobamba to learn about this work and its possible collaboration in environmental improvement strategies for the city.

- Update biannually the cadaster of parks, green areas and recreational areas of the city of Riobamba, this in function of the rapid population growth of the city.

- Socialize the existing ordinances so that the population public employees become aware of their obligations and rights over the use of green and recreational areas.

- Insert in the school and school curricula the chair of environmental education to develop in the children and young people the love for their local resource and their own well-being.

- Coordinate actions with the public, private and community sectors of Riobamba to organize family events where the psycho-physical benefits of the use of green and recreational areas are emphasized.

\section{Conclusiones:}

- At the end of the review of both local and international indicators, it was possible to obtain 6 criteria and 10 indicators, of which only 1 indicator is worked by the Municipality of Riobamba corresponding to green areas, the rest of the indicators 
are from experiences carried out in other cities of the world, that allowed to know the reality of Riobamba in its biodiversity.

- Using the geo-information technique, 229 areas of green and recreational areas were obtained, distributed as follows: 29 green areas (13\%), 112 parks (48\%), 25 sports courts (11\%) and 63 lots vacant lots (28\%), with a total of 119.58 hectares representing $4.08 \%$ of the total area of the city.

- With the results obtained from the baseline, 6 maps were represented with the relevant information of the indicators; type of building, existing green areas in the city, state of green areas, impermeability of green areas and parks that have trees.

- Through the application of the data matrix it was determined that the level of sustainability of the Riobamba city is at $61.97 \%$, identifying itself as a degree of environmental sustainability at the "Medium" level of biodiversity.

- The results obtained from the statistical analysis of satisfaction of the citizenship of the city shows that more than $80 \%$ of them do not agree with the works carried out by the GADM Riobamba due to the lack of importance given to the parks and areas green of the city.

\section{Referencias bibliográficas:}

Asamblea Nacional del Ecuador. (2016). Artículo 488, Código de Ordenamiento Territorial, Autonomía y descentralización. Quito - Ecuador.

Ayuntamiento de Málaga. (2009). Indicadores de la Sostenibilidad. Málaga - España.

Ciudades más verdes en América latina y el Caribe. ORGANIZACIÓN DE LAS NACIONES UNIDAS PARA LA ALIMENTACIÓN Y LA AGRICULTURA. 2014. Roma, pp. 50-53.

Conferencia Habitat III. La nueva agenda urbana. 2016. Conferencia de la ONU sobre la vivienda y el desarrollo urbano sostenible. Quito- Ecuador, pp. 20-27

Coordinadora Estatal de Productores de Café de Oaxaca (CEPCO). Video 7:51min. Observatorio TV. Publicado 14 de marzo de 2016. Recuperado el 10 de enero de 2017.

Manual del Sistema de indicadores ambientales. Sistema Único de información Ambiental (SUIA). 2014. Ministerio de Ambiente de Ecuador, pp. 22-30.

Quiroga, R. 2007. Indicadores ambientales y de desarrollo sostenible: avances y perspectivas para América Latina y el Caribe. Manuales. Serie 55. CEPAL-ONU. Diciembre 2007. Santiago de Chile, Chile, pp. 15-21 
February 08, 2019. Mapas del Ecuador. Recovered from

http://www.igm.gob.ec/work/files/downloads/mapafisico.html

October 25, 2018. Comisión económica para América Latina y el Caribe. Recovered from https://repositorio.cepal.org/bitstream/handle/11362/5498/1/S0700589_es,

December 12, 2018. Observatorio del sector social de la economía. Recovered from http://osse.org.mx/ December 20, 2016. Recovered from http://habitat3.org/wpcontent/uploads/Brochure-Espa\%C3\%B1ol-Web-final.pdf

April,19, 2019. Recovered from

http://suia.ambiente.gob.ec/documentos?p_p_id=20\&p_p_lifecycle=0\&p_p_stat e=normal\&p_p_mode=view\&p_p_col_id=column-

$1 \&$ p_p_col_pos=1\&p_p_col_count=2\&_20_struts_action=\%2Fdocument_librar y\%2Fview\&_20_folderId $=185876$

March 15, 2019. Ciudades más verdes de América Latina. Reporte de Food and agriculture organization of the united nation. Recovered from http://www.fao.org/ag/agp/greenercities/pdf/GGCLAC/Ciudades-mas-verdesAmerica-Latina-Caribe.pdf 


\section{PARA CITAR EL ARTÍCULO INDEXADO.}

Verdugo Bernal, C. M., Piray Quezada, M. I., Velasteguí Cáceres, J. D., \& Arias Guanga, M. G. (2020). Identificación de indicadores ambientales relacionados con el nivel de biodiversidad para determinar el turismo urbano sostenible utilizando geo tecnologías. Estudio de caso: Riobamba-Ecuador. Explorador Digital, 4(3), 78-91. https://doi.org/10.33262/exploradordigital.v4i3.1289

\section{\Ciencia}

El artículo que se publica es de exclusiva responsabilidad de los autores y no necesariamente reflejan el pensamiento de la Revista Explorador Digital.

El artículo queda en propiedad de la revista y, por tanto, su publicación parcial y/o total en otro medio tiene que ser autorizado por el director de la Revista Explorador Digital.
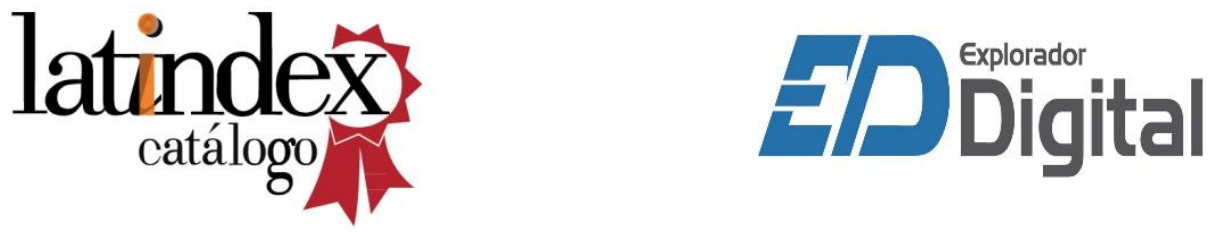